\title{
Glycerin from biodiesel in the feeding of red-egg layers
}

\section{Glicerina oriunda do biodiesel na alimentação de poedeiras de ovos vermelhos}

\author{
Grazielly Stefany Pinto Fontinele ${ }^{1 *}$; Silvana Cavalcante Bastos Leite ${ }^{2}$; \\ Carla Nágila Cordeiro ${ }^{3}$; Cláudia de Castro Goulart ${ }^{2}$; Adailton Camêlo Costa ${ }^{1}$; \\ Jeniffio Oliveira Neves ${ }^{1}$; Josefa Dêis Brito Silva ${ }^{4}$
}

\begin{abstract}
The aim of this study was to evaluate the effects of vegetable glycerin on performance and egg quality of red-egg layers in the second production cycle. A total of $252 \mathrm{Hy}$-Line Brown layers weighing 1.919 $\pm 0.095 \mathrm{~kg}$, at 90 weeks, were used in a completely randomized design with six treatments and seven birds per replication. The experiment lasted 84 days. Treatments consisted of a control diet (no glycerin) and five diets with increasing levels of vegetable glycerin $(2,4,6,8$, and $10 \%)$. The following variables were evaluated: feed intake ( $\mathrm{g} / \mathrm{bird} /$ day); egg production (\%); egg weight (g); egg mass ( $\mathrm{g} / \mathrm{bird} /$ day); conversion per egg mass $(\mathrm{kg} \mathrm{kg})$ and per dozen eggs $(\mathrm{kg} / \mathrm{dz})$; percentages of albumen, yolk, and shell; eggshell thickness $(\mathrm{mm})$; and egg specific gravity. $\left(\mathrm{Y}=67.69+54.23 \mathrm{X}, \mathrm{R}^{2}=0.78\right)$ and egg mass $(\mathrm{Y}=$ $\left.44.84+42.87 \mathrm{X}, \mathrm{R}^{2}=0.66\right)$ improved linearly with the glycerin levels. A quadratic effect was observed $\left(\mathrm{Y}=114.11+336.96 \mathrm{X}-3,169.6 \mathrm{X}^{2}, \mathrm{R}^{2}=0.52\right)$ on feed intake. In conclusion, glycerin can be used to partially replace corn in diets for layers in the second production cycle at inclusion levels of up to $10 \%$. Key words: Alternative feedstuff. Nutrition. Performance. Egg-laying.
\end{abstract}

\section{Resumo}

Objetivou-se avaliar os efeitos da glicerina vegetal sobre o desempenho e qualidade dos ovos de poedeiras de ovos vermelhos em segundo ciclo de produção. Foram utilizadas 252 poedeiras $H y$-Line Brown, pesando 1,919 \pm 0,095 kg com 90 semanas, em um delineamento inteiramente casualizado com seis tratamentos e sete aves por repetições. O experimento teve duração de 84 dias. Os tratamentos consistiram em uma dieta controle (sem glicerina), e cinco dietas com níveis de glicerina vegetal $(2,4$, 6,8 e 10\%). As variáveis avaliadas foram: consumo de ração (g/ave/dia), produção de ovos (\%), peso do ovo (g), massa de ovos (g/ave/dia), conversão por massa de ovos $(\mathrm{kg} / \mathrm{kg})$, conversão por dúzia de ovos $(\mathrm{kg} / \mathrm{dz})$, percentual de albúmen, gema e casca, espessura de casca $(\mathrm{mm})$ e gravidade específica dos ovos. A produção $\left(\mathrm{Y}=67.69+54.23 \mathrm{X}, \mathrm{R}^{2}=0.78\right)$ e massa de ovos $\left(\mathrm{Y}=44.84+42.87 \mathrm{X}, \mathrm{R}^{2}=\right.$ $0.66)$ melhoraram linearmente com os níveis de glicerina. Foi observado efeito quadrático ( $\mathrm{Y}=114.11$ + 336.96 X - 3.169.6 $\mathrm{X}^{2}, \mathrm{R}^{2}=0.52$ ) sobre o consumo de ração. Conclui-se que a glicerina pode ser utilizada em substituição parcial ao milho, nas dietas para poedeiras em segundo ciclo de produção, no nível de até $10 \%$ de inclusão.

Palavras-chave: Alimento alternativo. Desempenho. Nutrição. Postura.

\footnotetext{
${ }^{1}$ Discentes do Curso de Graduação em Zootecnia, Universidade Estadual Vale do Acaraú, UVA, Sobral, CE, Brasil. E-mail: grazielly_stefany@hotmail.com; adailton07nr@hotmail.com; jeniffioneves2009@hotmail.com

2 Prof ${ }^{\text {as }}$ Dr $^{\text {as }}$, UVA, Sobral, CE, Brasil. E-mail: silvanabastos2000@yahoo.com.br; clcgoulart@hotmail.com

${ }^{3}$ Discente do Curso de Mestrado do Programa de Pós-Graduação em Zootecnia, Universidade Federal do Ceará, UFC, Fortaleza, CE, Brasil. E-mail: carlinha_nagila@hotmail.com

${ }^{4}$ Prof $^{a}$, M.e, UVA, Sobral, CE, Brasil. E-mail: deisbrito@hotmail.com

* Author for correspondence
} 


\section{Introduction}

The poultry segment has shown a significant growth in the last decades as a result of the use of more productive and precocious lines associated with proper nutrition, health, and automation of facilities, which have all allowed Brazil to have a never-before observed productivity. A total of $31,775,108,157$ eggs were produced in 2012, and a $6.87 \%$ increase was observed in the 2013 production, totaling $34,120,752,432$ eggs, as compared with the previous year (UBABEF, 2014).

In commercial poultry production, the costs of feeding represent 60 to $70 \%$ (BUENO, 2014), with the energy component being one of the most costly of formulations. Therefore, alternative feedstuffs must be discovered to efficiently replace conventional ingredients, without interfering with the animal development.

The environmental concern and the growth of biodiesel production have propelled the increase in the number of studies on the inclusion of crude glycerin in animal nutrition. Glycerin is a by-product from biodiesel production that represents $10 \%$ of the total volume of biodiesel produced (PIRES et al., 2013) and is characterized as a high-energy feedstuff used efficiently by animals (MOREIRA; CARVALHO, 2009).

Purified glycerin has an array of applications, with its use extended to the composition of foods, beverages, cosmetics, and medication (MOREIRA; CARVALHO, 2009). However, in order for it to attain the degree of purity necessary for these purposes, it must undergo complex, high-cost processing steps (PERES et al., 2005).

Crude glycerin contains approximately 95\% glycerol in its composition (MOREIRA; CARVALHO, 2009), in addition to water, catalysts, alcohols, free fatty acids, propanediols, monoesters, glycerin oligomers, and polymers (LIMA et al., 2014). According to EFSA (2010), glycerin, or glycerol $(1,2,3,-$ propanetriol) is an organic alcohol whose molecule is formed by a carbon skeleton to which three hydroxyls are bound. It is a viscous, odorless, and colorless liquid with slightly sweetish flavor.

The crude glycerin derived from the biodiesel synthesis is obtained through the transesterification process, which is based on a chemical reaction that, in short, is the reaction between a vegetable oil and a simple alcohol, usually methanol or ethanol. The reaction is catalyzed by an acid or a base, using sodium hydroxide or potassium hydroxide (OLIVEIRA et al., 2013). In this reaction, the main molecules of oils and fat, named triacylglycerols, are separated into fatty acids and glycerin (LARSEN, 2009).

At present, research about the employment of renewable energy sources has been intensified. Therefore, studies involving the use of alternative feedstuffs, focusing on by-products, have been relevant. Because it is an excellent source of energy for pigs (LAMMERS et al., 2008a), poultry (JUNG; BATAL, 2011) and layers (LAMMERS et al., 2008b), glycerin can be added to diets substituting other energy sources.

Given the need for alternative ingredients that can substitute the conventional ones in diets while providing similar performance, vegetable glycerin emerges as an available item in the region at a rather fair cost, thus representing an option for the partial replacement of corn in poultry diets. Therefore, the objective of the present study was to evaluate the effect of vegetable glycerin on the performance and egg quality of red-egg layers in the second production cycle.

\section{Material and Methods}

Experimental procedures were approved by the Ethics Committee in Animal Experimentation (Câmara de Ética em Experimentação Animal CEUA), under case no. 003.05.014.UVA.504.03.

The experiment was conducted at the Experimental Farm (FAEX) of the Animal Science 
Course at the Center for Agricultural and Biological Sciences of State University Vale do Acaraú UVA, located in Sobral, CE, Brazil, comprising three 28-day cycles. A total of 252 Hy-Line Brown layers, at 90 weeks of age, in the 2 nd production cycle, weighing $1.919 \pm 0.095 \mathrm{~kg}$, were used. The experimental design was completely randomized, with six treatments and seven replications of six birds each.

Before the beginning of the experiment, birds were weighed and selected to obtain the experimental plots with uniform average weight and egg production, following recommendations proposed by Sakomura and Rostagno (2007).
The treatments tested here consisted of a control diet without vegetable glycerin and five diets with increasing levels of glycerin inclusion: $2,4,6,8$, and $10 \%$. The glycerin used in the experiment was donated by the refinery of Petrobrás S.A., located in Quixadá-CE, Brazil, and analyzed by its laboratory. The analysis results are described in Table 1. Experimental diets were isoprotein, isocaloric, and iso-amino acid (Table 2), formulated according to nutritional requirements suggested by the manual of the strain (HY-LINE MANUAL DE MANEJO, 2014), The composition of ingredients adopted in the formulation followed the recommendation of Rostagno et al. (2011).

Table 1. Composition and characteristics of glycerin used (fresh matter basis).

\begin{tabular}{lc}
\hline Item & Values \\
\hline Glycerol $^{1}, \%$ & 76.5 \\
Sodium chloride $^{1}, \%$ & 5,3 \\
Ash $^{1}, \%$ & 5,3 \\
Non-glycerin organic matter $^{1}, \%$ & 0,67 \\
Absolute density $^{1}, \mathrm{~kg} / \mathrm{m}^{3}$ & 1242,3 \\
$\mathrm{pH}^{1}$ & 5,5 \\
Methanol $^{1}, \%$ & 0,16 \\
Moisture $^{1}, \%$ & 17,6 \\
Aspect $^{1}$ & Clear \\
Color $^{1}$ & Yellow \\
Met. energy Poultry $^{2}$ & $3510 \mathrm{Kcal} / \mathrm{kg}$ \\
\hline
\end{tabular}

${ }^{1}$ Data provided by the Refinery Laboratory of Petrobras, in Quixadá-CE, Brazil.

${ }^{2}$ Met. energy Poultry (ROSTAGNO et al., 2011).

All birds received the same dairy management during the evaluated period, with water available $a d$ libitum. Diets were supplied in manual gutter-type feeders placed in front of each experimental unit.

At the end of each 28-day period, performance indices were measured for the evaluation of the effects of treatments. The following variables were evaluated: feed intake (g/bird/day), egg production (\%), egg weight (g), egg mass (g/bird/day), conversion per egg mass $(\mathrm{kg} / \mathrm{kg})$, and conversion per dozen eggs $(\mathrm{kg} / \mathrm{dz})$.
The following egg quality parameters were assessed at the end of each 28-day period: percentages of albumen (\%), yolk (\%), and shell (\%); eggshell thickness (mm); and egg specific gravity $\left(\mathrm{g} / \mathrm{cm}^{3}\right)$.

To determine the best glycerin inclusion level, treatments data were subjected to regression analysis at $5 \%$, and treatment means were compared with control group by Dunnett's test at 5\% significance level. These statistical analyses were performed using Statistical Analysis System software (SAS, 2000). 
Table 2. Centesimal and calculated nutritional composition of the experimental diet.

\begin{tabular}{lcccccc}
\hline \multirow{2}{*}{ INGREDIENT (kg) } & \multicolumn{7}{c}{ Vegetable Glycerin (\%) } \\
\cline { 2 - 7 } & 0 & 2 & 4 & 6 & 8 & 10 \\
\hline Grain corn & 66.690 & 64.146 & 61.599 & 59.051 & 56.503 & 53.955 \\
Soybean meal (45\%) & 20.451 & 20.932 & 21.417 & 21.902 & 22.387 & 22.872 \\
Limestone & 10.631 & 10.625 & 10.619 & 10.613 & 10.607 & 10.601 \\
Glycerin & 0.000 & 2.000 & 4.000 & 6.000 & 8.000 & 10.00 \\
Dicalcium phosphate & 1.339 & 1.345 & 1.351 & 1.357 & 1.363 & 1.369 \\
Vitamin-mineral supplement * & 0.400 & 0.400 & 0.400 & 0.400 & 0.400 & 0.400 \\
Common salt & 0.343 & 0.344 & 0.345 & 0.346 & 0.347 & 0.348 \\
Soy oil & 0 & 0.067 & 0.135 & 0.203 & 0.271 & 0.339 \\
DL-methionine, 99\% & 0.095 & 0.098 & 0.101 & 0.104 & 0.107 & 0.110 \\
L-lysine & 0.048 & 0.039 & 0.029 & 0.020 & 0.011 & 0.002 \\
\hline & Calculated Nutritional Composition & & & \\
\hline Metab. energy kcal/kg) & 2,751 & 2,751 & 2,751 & 2,751 & 2,751 & 2,751 \\
Crude protein (\%) & 15.13 & 15.13 & 15.13 & 15.13 & 15.13 & 15.13 \\
Calcium (\%) & 4.500 & 4.500 & 4.500 & 4.500 & 4.500 & 4.500 \\
Available phosphorus (\%) & 0.340 & 0.340 & 0.340 & 0.340 & 0.340 & 0.340 \\
Sodium (\%) & 0.170 & 0.170 & 0.170 & 0.170 & 0.170 & 0.170 \\
Total methionine + cystine (\%) & 0.590 & 0.590 & 0.590 & 0.590 & 0.590 & 0.590 \\
Total methionine (\%) & 0.369 & 0.371 & 0.373 & 0.375 & 0.377 & 0.378 \\
Total lysine (\%) & 0.690 & 0.690 & 0.690 & 0.690 & 0.690 & 0.690 \\
\hline
\end{tabular}

*PX POSTURA 0.4\% 500 TEC - Provides per kilogram: iron (min) $10.00 \mathrm{~g} \mathrm{~kg}$; copper (min): 2,500.00 mg kg; zinc (min): 20.00 $\mathrm{g} \mathrm{kg}$; manganese (min): $20.00 \mathrm{~g} \mathrm{~kg}$; iodine (min): $208.00 \mathrm{mg} \mathrm{kg}$; selenium (min): $75.15 \mathrm{mg} \mathrm{kg}$; vitamin A (min): 2,000,000.00 IU kg; vitamin D3 (min): 625,000.00 IU kg; vitamin E (min): 3,000.00; vitamin K3 (min): $395.92 \mathrm{mg} \mathrm{kg}$; folic acid (min): $74.25 \mathrm{mg}$ $\mathrm{kg}$; choline (min): $100.00 \mathrm{~g} \mathrm{~kg}$; niacin (min): 5,025.74 mg kg; pantothenic acid (min): 1,805.16 mg kg; vitamin B1 (min): 250.09 $\mathrm{mg}$ kg; vitamin B2 (min): 1,000.00 mg kg; vitamin B6 (min): 250,1 mcg; vitamin B12 (min): 2,400.00; methionine (min): 125.00 $\mathrm{g} \mathrm{kg}$; colistin (min) $1,750.00 \mathrm{mg} \mathrm{kg}$.

\section{Results and Discussion}

No significant differences were observed ( $\mathrm{P}>0.05$ ) for egg weight, conversion per mass, or conversion per dozen eggs. However a quadratic effect of glycerin levels was detected on feed intake (point of maximum: 6.16\%). Egg mass, however, improved linearly $(\mathrm{P}<0.05)$ with the glycerin levels added to the layer diets (Table 3), with a $5.4 \%$ increase estimated for egg production and $4.3 \mathrm{~g}$ for egg mass produced per day with inclusion of $10 \%$ vegetable glycerin in the diets. With regard to egg production, when compared with control treatment by Dunnett's test, only the birds fed the diet containing $10 \%$ glycerin showed values significantly higher than this.

A recognized fact is the intake capacity of redegg layers (JARDIM FILHO et al., 2005), which was verified in the present experiment even after inclusion of glycerin in the diets. This ingredient has been attributed the characteristic of improving the texture (PASQUETTI et al., 2014) and palatability (SILVA et al., 2013) of feeds, which are aspects responsible for increased feed intake. However, some studies have reported interference of some substances contained in crude glycerin that may lead to limitations to intake, such as the sodium content (GUERRA et al., 2011). Considering that the experimental diets were not corrected for sodium, since the composition of the ingredients of the formulae was extracted from Rostagno et al. (2011), which does not take into account any $\mathrm{Na}$ value as a component of glycerin, the elevated sodium content provided by the treatments with greater inclusion of glycerin (8 and 10\%) was likely responsible for the intake response found in the present study. These 
results confirm those obtained by Cerrate et al. (2006) and Guerra et al. (2011), in which inclusion of $10 \%$ crude glycerin in broiler diets negatively affected their intake.

Henz et al. (2014) worked with glycerin inclusion $(0,3,6,9,12$, and $15 \%)$ in diets for broilers in the period of 1 to 10 days of age and also found a quadratic effect of the glycerin levels on feed intake, at the maximum level of $9.02 \%$.

The experimental diets were isonutrient and formulated so as to meet the nutritional requirements of the birds, and thus only the percentage of glycerin differed between them. This ingredient has been attributed the characteristic of high absorption rate (YANG et al., 2012), by which it is converted to energy through multiple metabolic processes (DUARTE et al., 2014). Hence, the energy from glycerol was likely made available faster to the layers, providing the egg production results found here. Diverging results were published by Lammers et al. (2008b), Swiatkiewicz and Koreleski (2009), and Duarte et al. (2014), in which egg production was not affected by the increasing crude glycerin levels of the diet.

Table 3. Mean values for feed intake, production, egg weight, egg mass, conversion per egg mass (CEM), and conversion per dozen eggs (CDZ) of commercial brown-egg layers fed diets containing glycerin.

\begin{tabular}{ccccccc}
\hline $\begin{array}{c}\text { Glycerin } \\
\text { level }\end{array}$ & $\begin{array}{c}\text { Intake } \\
(\mathrm{g} / \text { bird/day })\end{array}$ & $\begin{array}{c}\text { Production } \\
(\%)\end{array}$ & Egg weight $(\mathrm{g})$ & $\begin{array}{c}\text { Egg mass } \\
(\mathrm{g} / \mathrm{bird} / \mathrm{day})\end{array}$ & $\begin{array}{c}\mathrm{CEM}^{1} \\
(\mathrm{~kg} / \mathrm{kg})\end{array}$ & $\begin{array}{c}\mathrm{CDZ}^{2} \\
(\mathrm{~kg} / \mathrm{dz})\end{array}$ \\
\hline $0 \%$ & 113 & 66.51 & 67.54 & 44.92 & 2.516 & 2.052 \\
$2 \%$ & 124 & 68.87 & 64.09 & 44.14 & 2.810 & 2.187 \\
$4 \%$ & 117 & 71.12 & 67.23 & 47.81 & 2.447 & 2.004 \\
$6 \%$ & 124 & 72.22 & 67.58 & 48.81 & 2.540 & 2.065 \\
$8 \%$ & 123 & 71.16 & 66.64 & 47.42 & 2.594 & 2.095 \\
$10 \%$ & 115 & $72.51^{*}$ & 66.7 & 48.36 & 2.378 & 1.928 \\
Linear & 0.4326 & $0.0043^{4}$ & 0.5988 & $0.0097^{5}$ & 0.3853 & 0.2611 \\
Quadratic & $0.0325^{3}$ & 0.1767 & 0.6720 & 0.3073 & 0.4343 & 0.3940 \\
Mean & 119.32 & 70.39 & 66.63 & 46.91 & 2.547 & 2.055 \\
SEM $^{6}$ & 1.193 & 0.643 & 0.262 & 0.466 & 0.040 & 0.030 \\
\hline
\end{tabular}

1- Conversion per egg mass; ${ }^{2-}$ Conversion per dozen eggs; ${ }^{3-} \mathrm{Y}=114.11+336.96 \mathrm{X}-3,169.6 \mathrm{X}^{2}, \mathrm{R}^{2}=0.52$ (point of maximum $6.16 \%) ;{ }^{4-} \mathrm{Y}=67.69+54.23 \mathrm{X}, \mathrm{R}^{2}=0.78 ;{ }^{5-} \mathrm{Y}=44.84+42.87 \mathrm{X}, \mathrm{R}^{2}=0.66 ;{ }^{6-}$ Standard error of the mean. * Dunnett's test at $5 \%$.

Considering that production values are used for the calculation of egg mass, and this variable thus being dependent on the former, the increasing linear response found for egg mass can be attributed to the result observed for egg production.

Boso (2011) worked with the glycerin inclusion levels of $0,1.5,3.0,4.5,6.0$, and $7.5 \%$ in the feeding of commercial white-egg layers at 39 weeks of age and observed a linear improvement in feed conversion with the increasing glycerin levels. These results differ from those of the present study.
No effects of glycerin levels were observed on any of the egg quality variables evaluated (Table 4).

The dietstested in this experimentwere formulated so as to meet the nutritional requirements of birds in the production stage they were in. Therefore, there were no alterations in the nutritional levels of the diets between treatments, factors that may influence the weight and quality of the eggs, which did not occur. Because the only difference between the treatments was the percentages of inclusion of glycerin, we can suggest that they did not affect the digestibility of the diet nutrients, thereby facilitating the use of glycerin in nutrition of commercial layers. 
Table 4. Mean values for percentages of albumen, yolk, and shell, eggshell thickness (ET), and specific gravity (SG) of commercial brown-egg layers fed diets containing glycerin.

\begin{tabular}{cccccc}
\hline Glycerin level & \% Albumen & \% Yolk & \% Shell & $\mathrm{ET}^{1}(\mathrm{~mm})$ & $\mathrm{SG}^{2}\left(\mathrm{~g} / \mathrm{cm}^{3}\right)$ \\
\hline $0 \%$ & 60.66 & 23.29 & 9.11 & 0.40 & 1.092 \\
$2 \%$ & 59.57 & 23.34 & 9.52 & 0.42 & 1.093 \\
$4 \%$ & 61.20 & 24.00 & 9.24 & 0.41 & 1.091 \\
$6 \%$ & 60.40 & 24.38 & 9.25 & 0.41 & 1.089 \\
$8 \%$ & 61.21 & 24.20 & 8.96 & 0.40 & 1.090 \\
$10 \%$ & 60.71 & 24.01 & 9.36 & 0.41 & 1.084 \\
Linear & 0.5382 & 0.1715 & 0.7626 & 0.5657 & 0.0641 \\
Quadratic & 0.9667 & 0.3375 & 0.9622 & 0.8173 & 0.4784 \\
\hline Mean & 60.62 & 23.87 & 9.24 & 0.41 & 1.090 \\
\hline SEM $^{3}$ & 0.207 & 0.200 & 0.060 & 0.002 & 0.0006 \\
\hline
\end{tabular}

${ }^{1-}$ Shell thickness; ${ }^{2-}$ Specific gravity; ${ }^{3}$ Standard error of the mean. $*$ Dunnett's test $5 \%$.

Results similar to those of the present study were reported by Swiatkiewicz and Koreleski (2009), who worked with commercial white-egg layers in the period of 28 to 53 weeks of age, using levels of inclusion of glycerin $(0,2,4$, and $6 \%)$, and reported that the egg quality parameters were not influenced by the glycerin levels in the diets.

Working with a mixed glycerin $(80 \%$ vegetable and $20 \%$ animal fat) in the diet of white-egg layers with inclusion of $0,1.5,3.0,4.5,6.0$, and $7.5 \%$, Duarte et al. (2014) observed that the egg quality parameters were not influenced by the increasing levels of this ingredient. These results are similar to those found here.

Contrasting results were reported by Mello et al. (2010), who worked with semi-purified glycerin at $1.5,3.0,4.5,6.0$, and $7.5 \%$ in the diet of whiteegg layers at 28 weeks of age and reported that the percentage of eggshell and specific gravity improved linearly with the inclusion of glycerin.

Although the data obtained in the present experiment demonstrated that the different levels of glycerin used were not able to improve the egg quality of the commercial layers, these results are relevant, considering that they were similar to those obtained by control group, which is an important option for monogastrics diets, thus demonstrating its possibility as a viable alternative feedstuff in the feeding of commercial layers.

\section{Conclusions}

Glycerin can be used to partially replace corn in diets for red-egg layers in the second production cycle at an inclusion level of up to $10 \%$ without compromising their performance or egg quality.

\section{References}

BOSO, K. M. O. Utilização de diferentes tipos de glicerina na alimentação de poedeiras comerciais. 2011. Dissertação (Mestrado em Zootecnia) - Universidade Estadual de Maringá, Centro de Ciências Agrárias, Maringá.

BUENO, C. F. D. Comparação de programas de alimentação para frangos de corte: 4 e 14 fases. 2014. Dissertação (Mestrado em Zootecnia) - Universidade Estadual Paulista. Faculdade de Ciências Agrárias e Veterinárias, Jaboticabal.

CERRATE, S.; YAN, F.; WANG, Z.; SACAKLI, P.; WALDROUP, P. W. Evolution of glycerine from biodiesel production as a feed ingredient the digestibility of fat in broilers- fat source and age. Journal of the Chinese Society of Animals Science, Fayetteville, v. 5, n. 11, p. 1001-1007, 2006.

DUARTE, C. R. A.; MURAKAMI, A. E.; BOSO, K. M. O.; EYNG, C.; OOSPINA-ROJAS, I. C.; MATUMOTOPINTRO, P. T. Mixed crude glycerin in laying hen diets: live performance and egg quality and fatty acid profile. Brazilian Journal of Poultry Science, Campinas, v. 16, $\mathrm{n}$. 4, p. 351-358, 2014.

EUROPEAN FOOD SAFETY AUTHORITY - EFSA. Panel on Contaminants in the Food Chain (CONTAM) 
- Scientific opinion on the abiotic risks for public and animal health of glycerine as co-product from the biodiesel production from Category 1 avnimal byproducts (ABP) and vegetable oils. European Food Safety Authority - EFSA Journal, Parma, v. 8, n. 12, p. 11-22, 2010.

GUERRA, R. L. de H.; MURAKAMI, A. E.; GARCIA, A. F. Q. M.; URGNANI, F. J.; MOREIRA, I.; PICOLI, K. P. Glicerina bruta mista na alimentação de frangos de corte (1 a 42 dias). Revista Brasileira de Saúde e Produção Animal, Salvador, v. 12, n. 4, p. 1038-1050, out/dez. 2011.

HENZ, J. R.; NUNES, R. V.; EYNG, C.; POZZA, P. C.; FRANK, R.; SCHONE, R. A.; OLIVEIRA, T. M. M. Effect of dietary glycerin supplementation in the starter diet on broiler performance. Cazech Jornal of Animal Science, Praga, v. 59, n. 12, p. 557-563, 2014.

HY-LINEMANUALDEMANEJO. Manual da linhagem: poedeiras comerciais Hy-Line Brown. Nova Granada, Hy-Line Red Book, 2014. Disponível em: <http://hyline. tempsite.ws/hyline/download/guia_ brown_2014.pdf $>$. Acesso em: 9 fev. 2016.

JARDIM FILHO, R. M.; STRINGHINI, J. H.; CAFÉ, M. B.; LEANDRO, N. S. M.; CUNHA, W. C. P.; NASCIMENTO JUNIOR, O. Influência das fontes e granulometria do calcário calcítico sobre o desempenho e a qualidade da casca dos ovos de poedeiras comerciais. Acta Scientiarum Animal Sciences, Maringá, v. 27, n. 1, p. 35-41, 2005.

JUNG, B.; BATAL, A. B. Nutritional and feeding value of crude glycerin for poultry. 1. Nutritional value of crude glycerin. Journal of Applied Poultry Research, Oxford, v. 20, n. 4, p. 162-167, 2011.

LAMMERS, P.; KERR, B. J.; HONEYMAN, M. Nitrogen-corrected apparent metabolizable energy value of crude glycerol for laying hens. Journal of Animal Science, Champaign, v. 87, n. 1, p. 104-107, 2008 b.

LAMMERS, P. J.; KERR, B. J.; WEBER, T. E.; DOZIER, W. A.; KIDD, M. T.; BREGENDAHL, K.; HONEYMAN, M. S. Digestible and metabolizable energy of crude glycerol for growing pigs. Journal of Animal Science, Champaign, v. 86, n. 3, p. 602-608, 2008a.

LARSEN, A. C. Co-digetão anaeróbia de glicerina bruta influênte. 2009. Dissertação (Mestrado em Engenharia Agrícola) - Universidade Estadual do Oeste do Paraná, Cascavel.
LIMA, D. C. L.; NETTO, M. V. T.; FELIX, A. P.; MARCELINO, B. M.; OLIVEIRA, S. G.; MAIORKA, I. A. Digestibilidade e energia metabolizável da glicerina em cães. Ciência Rural, Santa Maria, v. 44, n. 8, p. 14521456, 2014.

MELLO, K. S.; BOSO, K. M. O.; SANTOS, T. C.; EYNG, C.; DUARTE, C. R. A.; MURAKAMI, A. E. Glicerina semi-purificada mista na alimentação de poedeiras comerciais. In: ENCONTRO ANUAL DE INICIAÇÃO CIENTÍFICA, 19., 2010, Guarapuava. Anais... Guarapuava: Universidade Estadual do CentroOeste, 2010.

MOREIRA, I.; CARVALHO, P. L. O. Glicerina na alimentação de suínos. Serrana nutrição animal. 95. ed. Maringá: Serrana Nutrição Animal, 2009. (Boletim técnico). Disponível em: http://www.serrana.com.br/ NutricaoAnimal/BoletimTecnico/Novembro2009.pdf>. Acesso em:15 fev. 2016.

OLIVEIRA, J. S.; ANTONIASSI, R.; FREITAS, S. C.; MÜLLER, M. D. Composição química da glicerina produzida por usinas de biodiesel no Brasil e potencial de uso na alimentação animal. Ciência Rural, Santa Maria, v. 43, n. 3, p. 509-512, mar. 2013.

PASQUETTI, T. J.; FURLAN, A. C.; MARTINS, E. N.; TON, A. P. S.; BATISTA, E.; POZZA, P. C.; GRIESER, D. O.; ZANCANELA, V. Glicerina bruta para codornas de corte, de um a 14 e de 15 a 35 dias de idade. Arquivo Brasileiro de Medicina Veterinária e Zootecnia, Belo Horizonte, v. 66, n. 5, p. 1547-1556, 2014.

PERES, J. R. R.; FREITAS JUNIOR, E.; GAZZONE, D. L. Biocombustíveis. Uma oportunidade para o agronegócio brasileiro. Revista da Política Agrícola, Brasilia, v. 1, n. 1, p. 31-41, 2005.

PIRES, P. G. S.; MENDES, J. V.; RICCI, G. D. A utilização da glicerina na nutrição de monogástricos. In: SIMPÓSIO DE SUSTENTABILIDADE E CIÊNCIA ANIMAL, 3., 2013, Pirassununga. Anais... Pirassununga: Faculdade de Medicina Veterinária e Zootecnia da Universidade de São Paulo, p. 1-3, 2013.

ROSTAGNO, H. S.; ALBINO, L. F. T.; DONZELE, J. L.; GOMES, P. C.; OLIVEIRA, R. F.; LOPES, D. C.; FERREIRA, A. S.; BARRETO, S. L. T.; EUCLIDES, R. F. Tabelas brasileiras para aves e suínos: composição de alimentos e exigências nutricionais. 3. ed. Viçosa, MG: UFV, 2011. $252 \mathrm{p}$.

SAKOMURA, N. K.; ROSTAGNO, H. S. Métodos de pesquisa em nutrição em monogástricos. Jaboticabal: FUNEP, 2007. $283 \mathrm{p}$. 
SILVA, S. C. C.; GASPARINO, E.; VOLTOLINI, D. M.; MARCATO, S. M.; TANAMATI, F. Expressão do mRNA de genes mitocondriais e desempenho produtivo de codornas alimentadas com glicerol. Pesquisa Agropecuária Brasileira, Brasília, v. 48, n. 2, p. 228-233, 2013.

STATISTICAL ANALYSIS SYSTEM INSTITUTE SAS Institute. SAS ${ }^{\circledR}$. User's guide: statistics. Version $10^{\text {th }}$. Cary: SAS Institute Inc, 2000.
SWIATKIEWICZ, S.; KORELESKI, J. Effect of crude glycerin level in the diet of laying hens on egg performance and nutrient utilization. Poultry Science, Savoy, v. 88, n. 3, p. 615-619, 2009.

UNIÃO BRASILEIRA DE AVICULTURA - UBABEF. Relatório anual. São Paulo: Aquarela S.A, 2014. Disponível em: $<$ http://abpa-br.com.br/files/publicacoes/ 8ca705e70f0cb110ae3aed 67d29c8842.pdf>. Acesso em: 5 set. 2015.

YANG, F.; HANNA, M. A.; SUN, R. Value-added uses for crude glycerol-a byproduct of biodiesel production. Biotechnology for Biofuels, Lincoln, v. 5, n. 13, p. 11891196, 2012. 